\title{
Students Perception About Digital Financial Services
}

\author{
Elena Moreno-García ${ }^{1,2}$, Arturo García-Santillán ${ }^{1,2} \&$ Damaris Platas Campero ${ }^{2}$ \\ ${ }^{1}$ Misantla Institute of Technology, Veracruz, Mexico \\ ${ }^{2}$ UCC Business School, Universidad Cristóbal Colón, Veracruz, Mexico \\ Correspondence: Elena Moreno-García, Instituto Tecnológico Superior de Misantla. Km. 1.8 Carretera a Loma del \\ Cojolite, C.P. 93821, Misantla, Veracruz, México.
}

Received: March 14, 2021

doi:10.5430/ijfr.v12n4p212
Accepted: April 19, 2021

Online Published: May 13, 2021

URL: https://doi.org/10.5430/ijfr.v12n4p212

\begin{abstract}
The purpose of this research is to determine how the students from a Mexican university perceive the different digital financial services. For the study, the Durai and Stella (2019) test was used, which is made up of twelve indicators in a Likert format to assess the perception of digital services, based on their convenience, adaptability, affordability, security, user-friendliness, trailing fee, accurate timing, online monthly statement, quick financial decision making, interbank account accessibility and internet connectivity. The main findings point to the satisfaction that respondents feel towards digital financial services in the five dimensions that were studied: Internet Banking, Mobile Banking, Mobile Wallet, Credit Cards and Debit Cards. Student's perception was extremely satisfactory towards Debit Card services, especially on the indicators of adaptability, affordability, security, user-friendliness, accurate timing, online monthly statement and portability. In addition, the Mobile Banking services had a positive impact on the Interbank account accessibility and Internet Connectivity. This could be explained by the way these current generations of young millennials easily handle technological use.
\end{abstract}

Keywords: financial services, financial inclusion, students, perception

\section{Introduction}

Today, the automation of processes has revolutionized human activity in practically all sectors of the economy. As a result, digital transformation paves the way to generate a total change in companies and in governmental and non-governmental organizations.

Digitalization is revolutionizing our lives as it multiplies business opportunities for companies and, at the same time, broadens the range of products and services available to consumers (OECD, 2018).

The competitiveness that companies seek will not be possible if they do not modify the traditional processes they have been operating with. The current reality of the markets demands new forms of service and product.

Digitalization has become a fundamental step in moving towards this change. This innovation brings competitive success to companies and other organizations that interact in modern society and in today's markets of course.

Digitalization has brought great benefits, since it encourages innovation and leads companies to reinvent themselves in new business models, increases operational efficiency and ultimately significantly improves competitiveness.

The financial field has not been left behind. It is cutting-edge and always seeking to satisfy the demands of users and carrying out strategies to attract new users, the latter, as part of a trend of financial inclusion that has become a topic of global agenda (G-20).

In this regard, the World Bank (2018) has pointed out that the use of technologies "has facilitated the access of small companies and the different strata of the population that could hardly access financial services, with benefits such as lower costs and less risk in the application and use of these services.

One of these emerging technologies, which has been a great contribution to society, is the so-called Information and Communication Technology or by its acronym (ICT). About this, Ávila (2013) defines Information and Communication Technologies as the set of technological elements that allow the processing of information, in an analog or digital way, for the benefit of people.

It is important to point out that, to ensure the permanence of the services or products of an organization in a certain period of time, it is necessary to design and implement digital innovation strategies. In this way, new products and 
services are introduced that help generate jobs and of course implement innovation in business models (World Bank, 2019).

Other benefits that are obtained through the implementation of digital innovation strategies through ICT are the broad territorial scope, and greater citizen participation through their use. The World Bank (2012) announced in its report "Information and Communications for Development" that the number of subscribers to mobile services grew from 1000 million in 2000, to 6000 million by 2012 and the number of internet users increased 20 times. In this way, we can infer that $91 \%$ of the population of developing countries have access to ICT-related services.

As part of this trend, financial institutions have carried out a deep change process, by implementing digital innovation strategies in their services to achieve greater coverage, both of users and territory, as stated by the World Bank (2014).

The design and implementation of technological tools that serve as a platform to increase services and reach disadvantaged areas in a timely manner, through the integration of Information and Communication Technologies in the financial sector, have favored the emergence of the digitalization of services. This constitutes the basis for the creation of the Digital Financial System or by its acronym DFS which is the object of this research.

The CGAP Consultative Group to Assist the Poor (2015) defines the digital financial system as: "Digital access and use of formal financial services by excluded and underserved populations. On the other hand, the international organization Alliance for Financial Inclusion [AFI], (2016) specifies that the DFS is made up of a "wide range of financial services accessed and delivered through digital channels, including payments, credit, savings, remittances and insurance".

Since the introduction of ICT in the financial sector, it has been possible to offer better products and services to the population, in addition to reaching places that were previously unbanked. With this, financial services will keep on transforming continuously with the appearance of new technologies. Therefore, if one of the fundamental purposes of the digital financial system is to achieve greater coverage in the population, it is relevant to pose the questions that emerge from the approach of the phenomenon under study.

If the digital financial system is a channel that favors the reach and coverage of the banked and unbanked population, it is worth asking ourselves: How does the population perceive financial digitalization?

The Organization for Economic Cooperation and Development [OECD], (2016) has indicated that Information and Communication Technologies applied to financial services could help to include the non-user population, while the AFI (2010) notes that the use of mobile technology in the financial system facilitates the emergence of new products and services.

All these ranges of options and benefits offered by digital financial services today are accompanied by certain risks to which the user is exposed. The AFI (2010) identifies the following risks in the use of mobile technology in financial services: operational, prudential, availability and quality of service, the communication protocol and data storage.

In short, these elements that arise with the use of Information and Communication Technologies in financial services can lead to changes in the experience lived by the user and non-user population of these services. Vargas (1994) explains: "that perception is relative to the historical-social situation, since it has a spatial and temporal location, it depends on changing circumstances and the acquisition of novel experiences that incorporate other elements into the previous perceptual structures, modifying them and adapting them to the conditions".

That is why this study is important; it seeks to know how students at higher education institutions perceive the digital financial system. In particular, university students are an interesting population to explore in this sense, considering that the university plays a relevant role in facing the challenge of acquiring skills in the use of ICT. University also participates in the dissemination and improvement of electronic learning among all the agents that are involved in the education process, as well as in the development of knowledge, skills, abilities in the management of technological tools, that is, in the development of the technological expertise of university students (Torres, 2015).

\section{Literature Review}

Álvarez, Paramo, and Carpio (2012) argue that in Mexico, one of the factors that influence the persistence of inequity, poverty, and the slow growth of less developed areas, rural and urban, is financial exclusion. In this sense, young people are one of the most vulnerable groups (Babajic, Okicic and Kokorovic, 2018).

Various studies have provided evidence that has enriched the debate on financial inclusion, in which key factors have been identified such as the digitization of financial services (Katz, 2012; Preciado-Ortiz and Moreno, 2015; Alcívar 
and Franco, 2016; Gonzales, 2017; Torres and Luna, 2017; Escalera-Chávez, Tejeda-Peña \& García-Santillán, 2017; Peterson, 2018 and Durai and Stella 2019).

Financial inclusion strengthens the economy. Nowadays, it is imperative that any regime create the conditions that allow individuals, households and institutions to have access to banking services (Damodaran, 2013). In order to reach this objective, it is strategic that the future users have a good perception of banking services. Perception is one of the psychological factors that can influence consumer purchase behavior. It is the process by which an individual selects, organizes and interprets the information he or she receives from the environment (Sheth et al., 2004 cited in Wee, Bin, Zakuan, Mohd, Ismail and Ishak, 2014).

Finau, Rika and Samuwai (2017) carried out a study on the perception that Fijians had about digital financial services with the intention of identifying what factors could promote or prevent their adoption. The findings demonstrate that perception of digital financial services is influenced by financial literacy and that young consumers appreciate the time saved using DFS. Higher income earners also appreciate timesavings but they also value safety. Results also show that ethnicity, gender and general education levels do not significantly affect perceptions of DFS.

Singhania and Sardana (2018) explored the level of adoption and perception that urban consumers in India have of digital financial services. The study focused on acceptability, use, beliefs, and incentive patterns among Indians. The results show that an urban Indian consumer would adopt digital finance only if it is viewed to be more convenient, reliable, secure, and less costly in terms of time and money.

Redelinghuis and Rensleigh (2010) carried out a research among 138 graduates of the University of Johannesburg with the intention of knowing customers' perception of internet banking regarding the protection of information when using banking services and products on the internet. The results show that a significant percentage of the population $(68.3 \%)$ state that they feel safe using internet banking. In addition, $71.6 \%$ of those surveyed perceive that financial institutions use appropriate technologies to protect their financial information. The results also revealed an increase in the number of young people who are requiring this service via mobile on devices such as their cell phones.

Wibella, Fahmi \& Saptono (2018) examined the factors that influence the acceptance of consumers of digital financial services in Bogor, Indonesia. Based on the results of this research, perceived usefulness have no significant effect to intention to use digital financial services. While perceived ease of use and credibility have significantly positive effect.

Widjana, M.A. \& Rachmat, B. (2011) determine the factors influencing acceptance level of internet banking by the bank customers in Surabaya, Indonesia regarding awareness of service, security, quality of internet connection, computer self eficacy, perceived usefulness, perceived ease of use, perceived enjoyment, trust, attitude towards using, and adoption intention. The results of this research show that only the relationship between awareness of service to the perceived usefulness and security to the perceived usefulness have no significant relationship.

Literature shows studies on the perception about digital financial services considering demographic variables. Even studies that explore perception of DFS focusing on acceptability, use, beliefs and protection of information. This research has the purpose to evaluate the perception that the university student has towards digital financial services analyzing the frequencies of Internet Banking, Mobile Banking, Mobile Wallet, Credit Cards and Debit Cards in twelve indicators: convenience, adaptability, affordability, security, user-friendliness, low trailing fee, accurate timing, online monthly statement, quick financial decision making, interbank account accessibility, internet connectivity, and portability.

A priori, it is established as a hypothesis for each of the dimensions and their indicators that the majority of students have a negative perception of digital financial services.

\section{Methodology}

It is a non-experimental study, therefore, at no time will the antecedent variables $(\mathrm{X})$ be manipulated in an attempt to modify the effects (Y), hence the type of study is descriptive and cross-sectioned, in the idea of being able to describe the response frequencies towards each of the twelve indicators in which the five dimensions of the DFS are evaluated.

The sample is non-probabilistic, it is conveniently self-determined since there was direct contact with the authorities of some private education schools in Boca del Río, Veracruz in Mexico. The instruction and authorization was that the survey could be applied to those students who agreed to participate. The total number of high-level students surveyed was 199, who study the following degrees: Accounting (27), Computer Systems Engineering (7), Law (81), English Teaching (1), Dentistry (15), Computer Science (1) and Foreign Trade (67) 
The common denominator of the sample is that they are university students, enrolled and up to date with their school obligations. In addition, due to the economic status they enjoy as students of prestigious private universities in Veracruz, Mexico, it would be more feasible for them to frequently use the services offered by Financial Institutions, both locally and from other contexts.

\subsection{Measurement Instrument and Technique}

In order to obtain data for the development of the empirical study, the Durai and Stella test (2019) is used. This consists of a Likert-type scale that integrates the five main digital systems offered by banks to carry out financial operations. The DFS Model proposed by Durai and Stella (2019) measures the users' perception of Digital Financial Services and is made up of two sections; the first section refers to the socio-demographic profile of the respondent. The second section measures the perception of each Digital Financial Service (Figure 1) using the twelve indicators: convenience, adaptability, affordability, security, user-friendliness, low trailing fee, accurate synchronization, online monthly statement, quick financial decision making, interbank account accessibility, internet connectivity and portability. The analysis of the frequencies obtained is shown graphically by dimension and indicators, in addition the $\mathrm{Z}$ test is used to prove the proportions hypotheses for each of the five variables in their twelve indicators, from the following calculation.
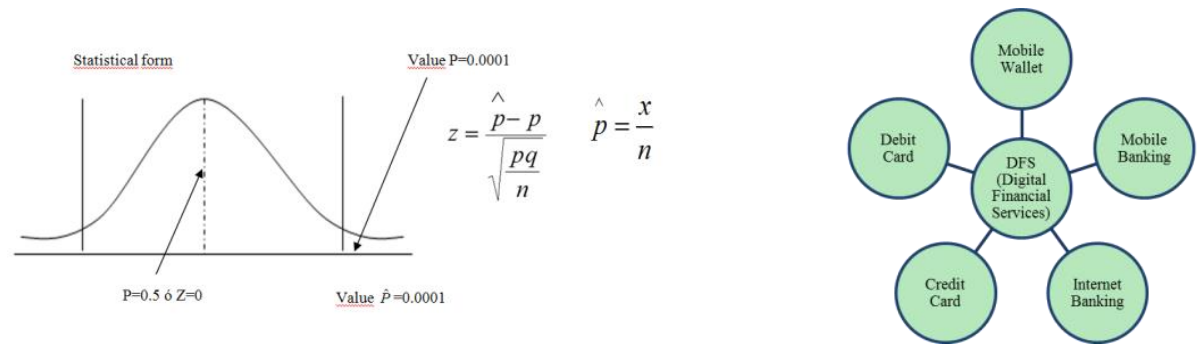

Figure 1. DFS model (Durai \& Stella, 2019)

\section{Findings}

The main characteristics of the participants: $(63=31.66 \%)$ are male and $(136=68.34 \%)$ are female, $(163=81.91 \%)$ are between 18 and 28 years old, $(24=12.06 \%)$ between 29 and 39 years old, $(11=5.53 \%)$ between 40 and 50 years old and $(1=0.5 \%)$ over 51 years old. About their marital status: $(162=181.41 \%)$ are single, $(22=11.06 \%)$ are married, $(2=1.0 \%)$ are widowed and $(13=6.53 \%)$ live in free union and finally $(84=42.21 \%)$ are employees, $(15=$ $7.54 \%)$ have their own business, $(20=10.05 \%)$ are employees and have their own business and $(80=40.20 \%)$ do not have a job. Table 1 shows a convenience test of the variables.

Table 1. H1-H5 convenience test

\begin{tabular}{|c|c|c|c|c|c|c|c|c|c|c|c|c|}
\hline $\begin{array}{l}\text { Convenience } \\
\text { variable }\end{array}$ & & $\mathrm{X}$ & $\mathrm{n}$ & $\hat{p}$ & $\mathrm{p}$ & $\begin{array}{l}q= \\
1-p\end{array}$ & $\begin{array}{l}\hat{p} \\
=-p\end{array}$ & $\sqrt{\frac{p q}{n}}$ & $\mathrm{Z}$ value & $\begin{array}{l}\text { Critical } \\
\text { value of } \\
\text { tables }\end{array}$ & $\begin{array}{l}\text { Pvalue } \\
\text { (1-critical } \\
\text { value of tables }\end{array}$ & Decision \\
\hline $\begin{array}{l}\text { Internet } \\
\text { banking }\end{array}$ & H1 & 24 & 199 & 0.121 & 1 & 0.5 & -0.379 & 0.035 & -10.70 & 0.0001 & 1.000 & $\begin{array}{ll}\text { Not rejected } \\
\text { Ho }\end{array}$ \\
\hline $\begin{array}{l}\text { Mobile } \\
\text { banking }\end{array}$ & $\mathrm{H} 2$ & 16 & 199 & 0.80 & 1 & 0.5 & -0.420 & 0.035 & -11.84 & 0.0001 & 1.000 & $\begin{array}{ll}\text { Not rejected } \\
\text { Ho }\end{array}$ \\
\hline $\begin{array}{l}\text { Mobile } \\
\text { wallet }\end{array}$ & $\mathrm{H} 3$ & 32 & 199 & 0.161 & 1 & 0.5 & -0.339 & 0.035 & -9.57 & 0.0001 & 1.000 & $\begin{array}{ll}\text { Not rejected } \\
\text { Ho }\end{array}$ \\
\hline Credit card & $\mathrm{H} 4$ & 20 & 199 & 0.101 & 1 & 0.5 & $-0-399$ & 0.035 & -11.27 & 0.0001 & 1.000 & $\begin{array}{ll}\text { Not rejected } \\
\text { Ho }\end{array}$ \\
\hline Debit card & $\mathrm{H} 5$ & 9 & 199 & 0.045 & 1 & 0.5 & -0.455 & 0.035 & -12.83 & 0.0001 & 1.000 & $\begin{array}{ll}\text { Not rejected } \\
\text { Ho }\end{array}$ \\
\hline
\end{tabular}

Source: own. 
As shown in Table 1 decision is not to reject Ho for the five dimensions of the study. In all cases, absolute value of $\mathrm{Z}$ is greater than critical value of tables.

In relation to the research question that asks: How do the user and non-user populations of financial services perceive financial digitalization? Next, analysis of each of the twelve indicators of the five dimensions of the DFS construct is shown. Therefore, this section show a description of the frequencies observed in each of the variables and their corresponding dimensions. For this, a figure per attribute is displayed.

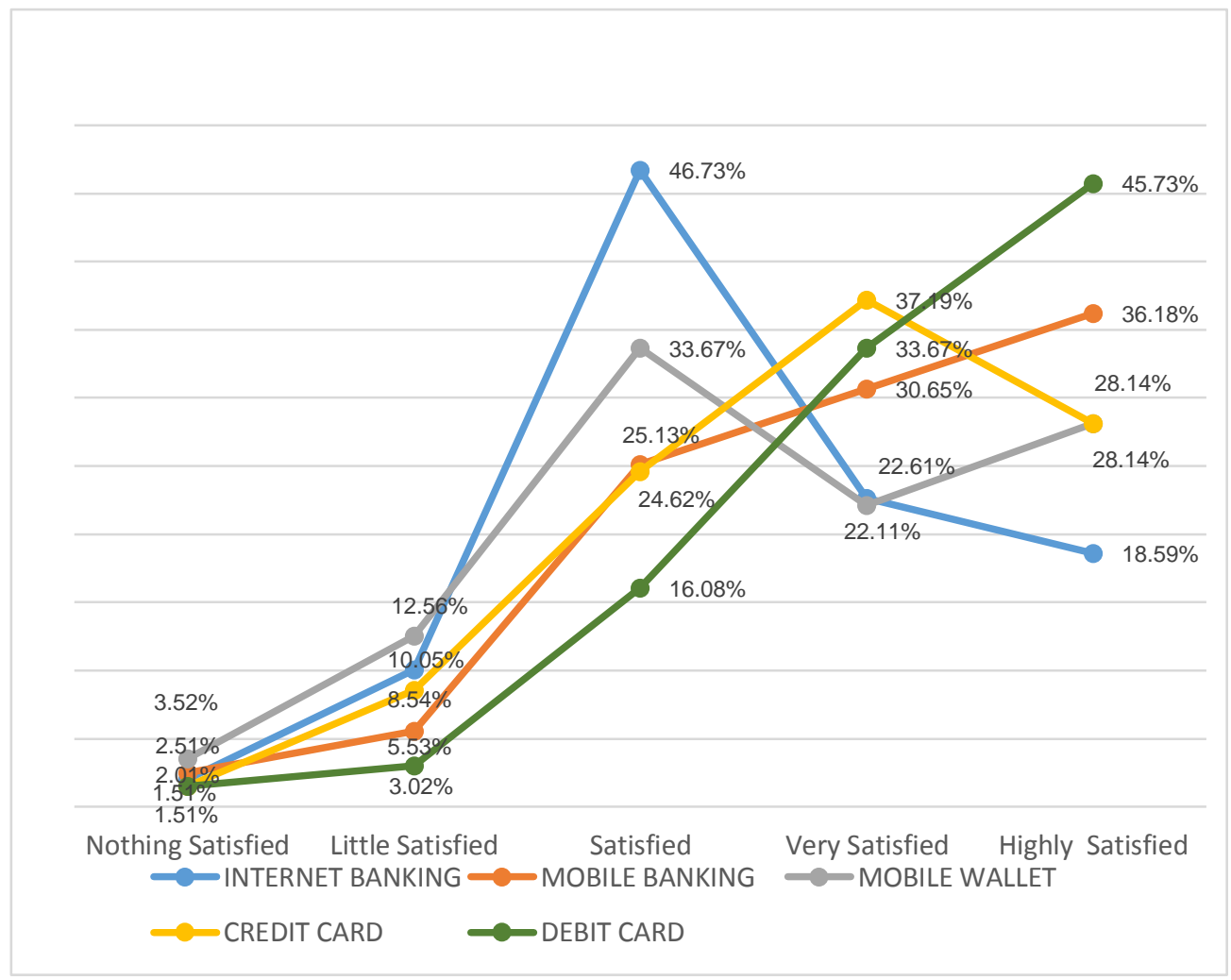

Figure 2. Convenience in digital financial services (own)

As Figure 2 shows, the frequencies obtained in the different levels of satisfaction of the Convenience indicator in the five dimensions were found to have a positive response, considering the levels of satisfaction. From the frequencies obtained in the five dimensions, the highest percentages are in the level of satisfied to highly satisfied, being the Internet Banking dimension with a $46.73 \%$ of respondents satisfied, followed by Debit Card with a $45.73 \%$ highly satisfied.

In relation to Adaptability, most of it is perceived as highly satisfactory in Debit Card and Credit Card services, with $48.24 \%$ and $41.21 \%$ respectively, unlike Internet Banking that only had $9.55 \%$ of the users interviewed; see Figure 3. 


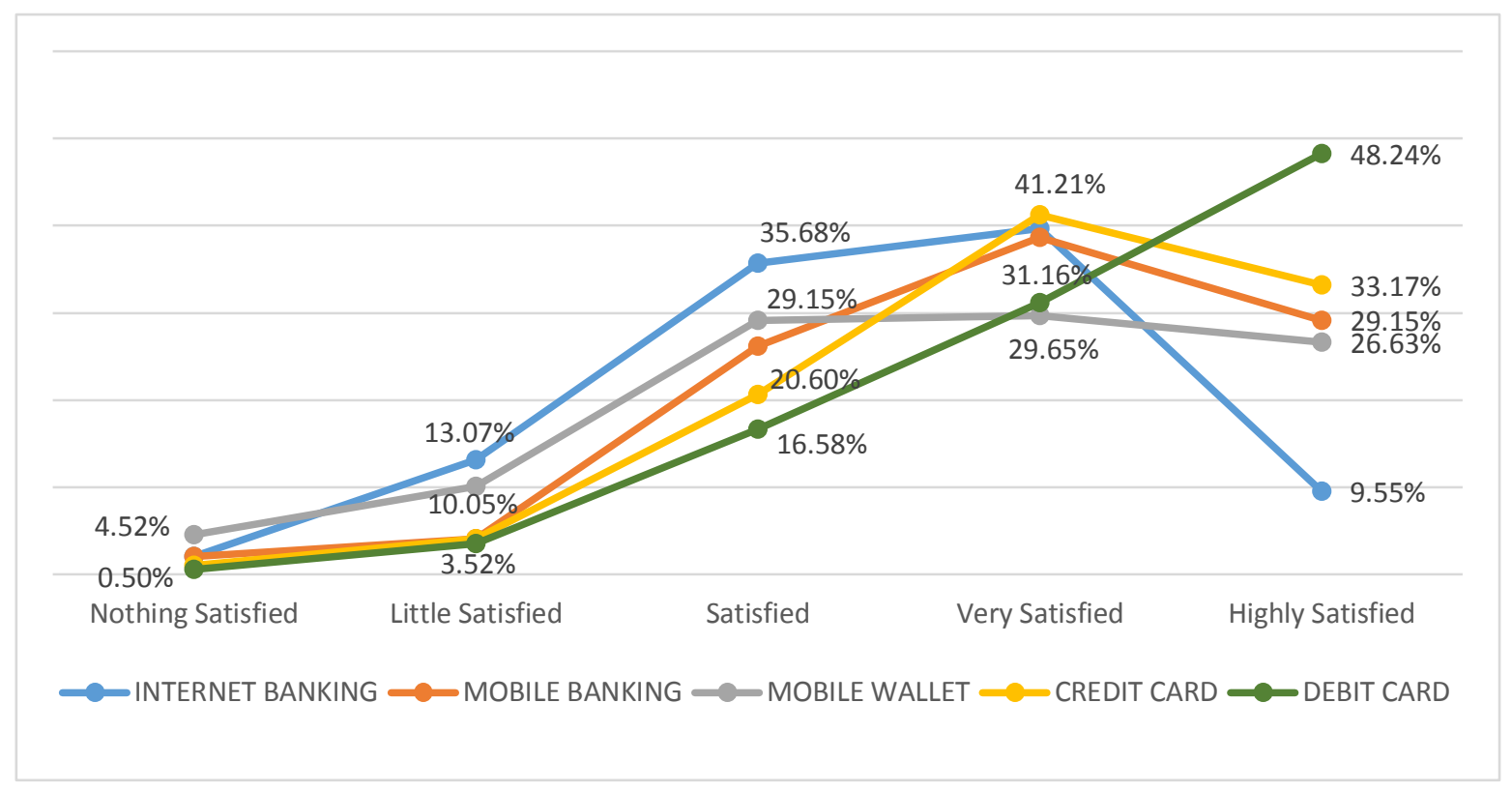

Figure 3. Adaptability in digital financial services (own)

As for Affordability, in Figure 4, it was detected that 51.26\% of the users interviewed were highly satisfied with the Debit Card service, followed by Mobile Banking with 37.19\%.

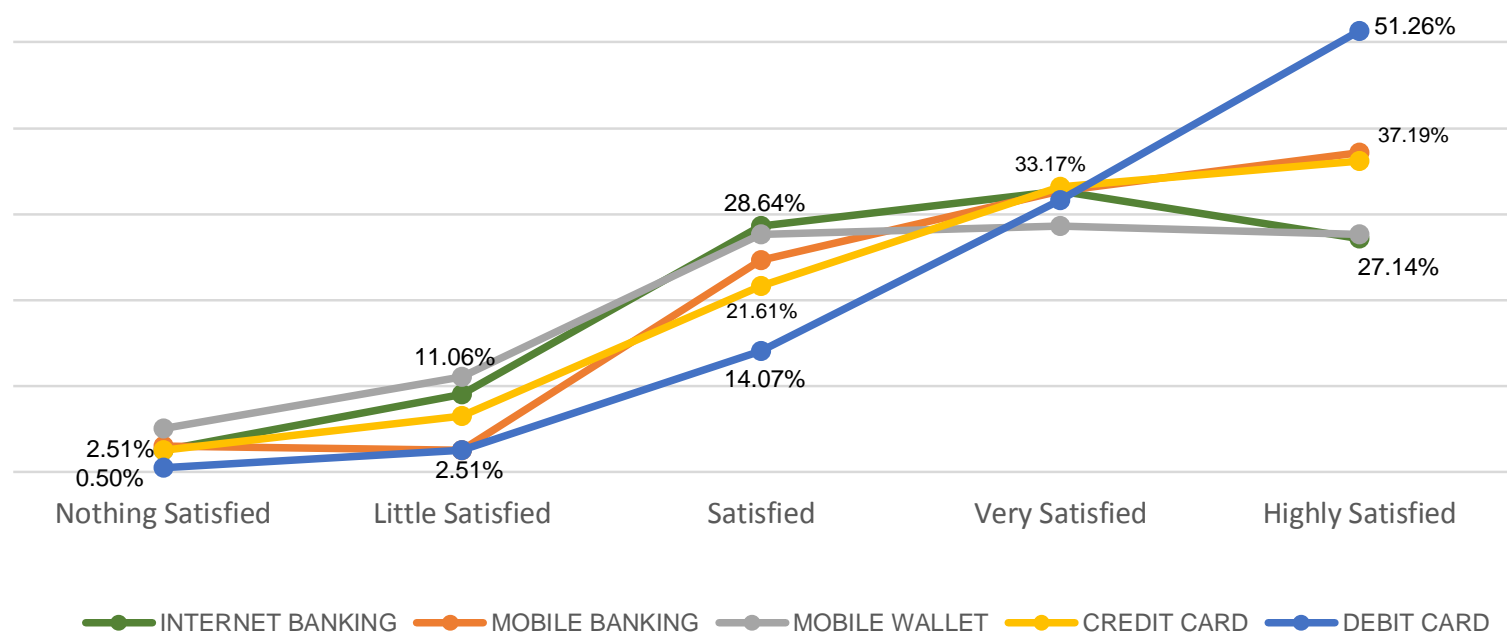

Figure 4. Affordability in digital financial services (own)

Similarly, users consider that the Debit Card service is the one that offers the maximum satisfaction, in terms of User-Friendliness, with 59.30\% approval versus only $28.14 \%$ in the Internet Banking system; see Figure 5. 


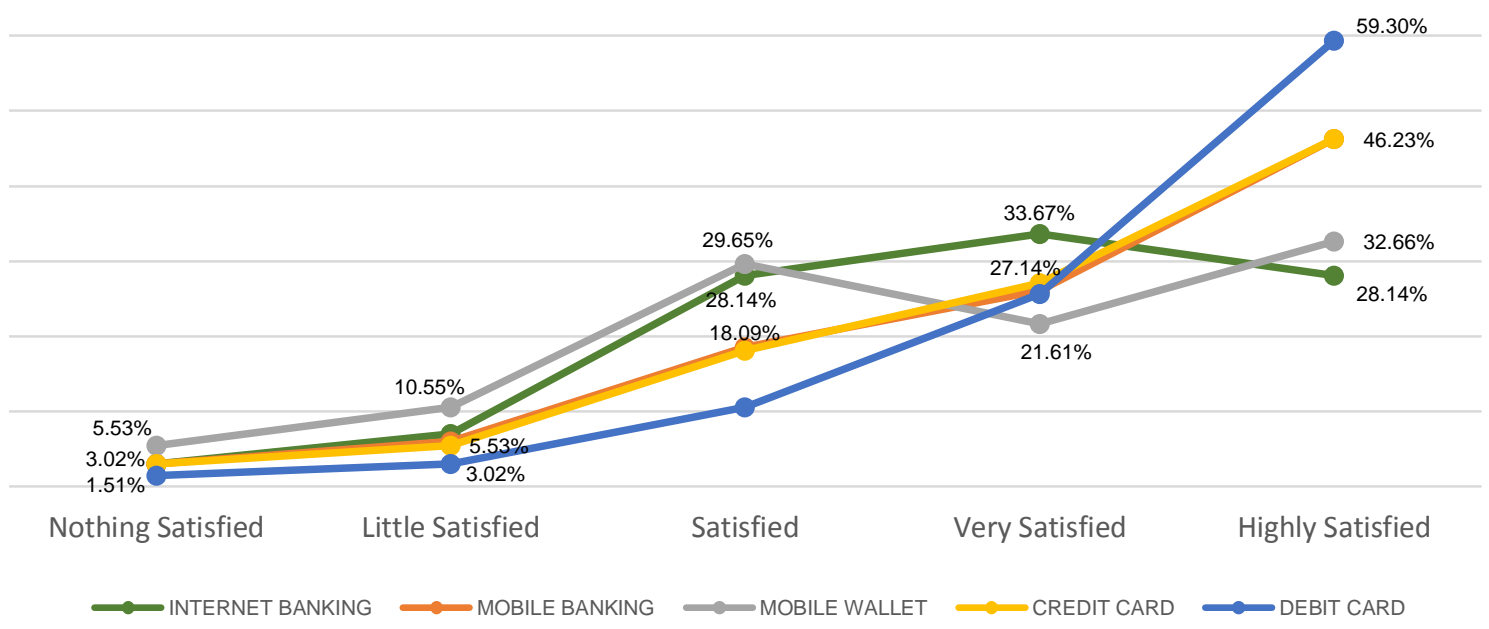

Figure 5. User-Friendly in digital financial services (own)

On the other hand, the following figure shows a similarity in the satisfactory perception of the Security dimension in Internet Banking systems with 34.67\% and in Debit Cards with 35.18\%.

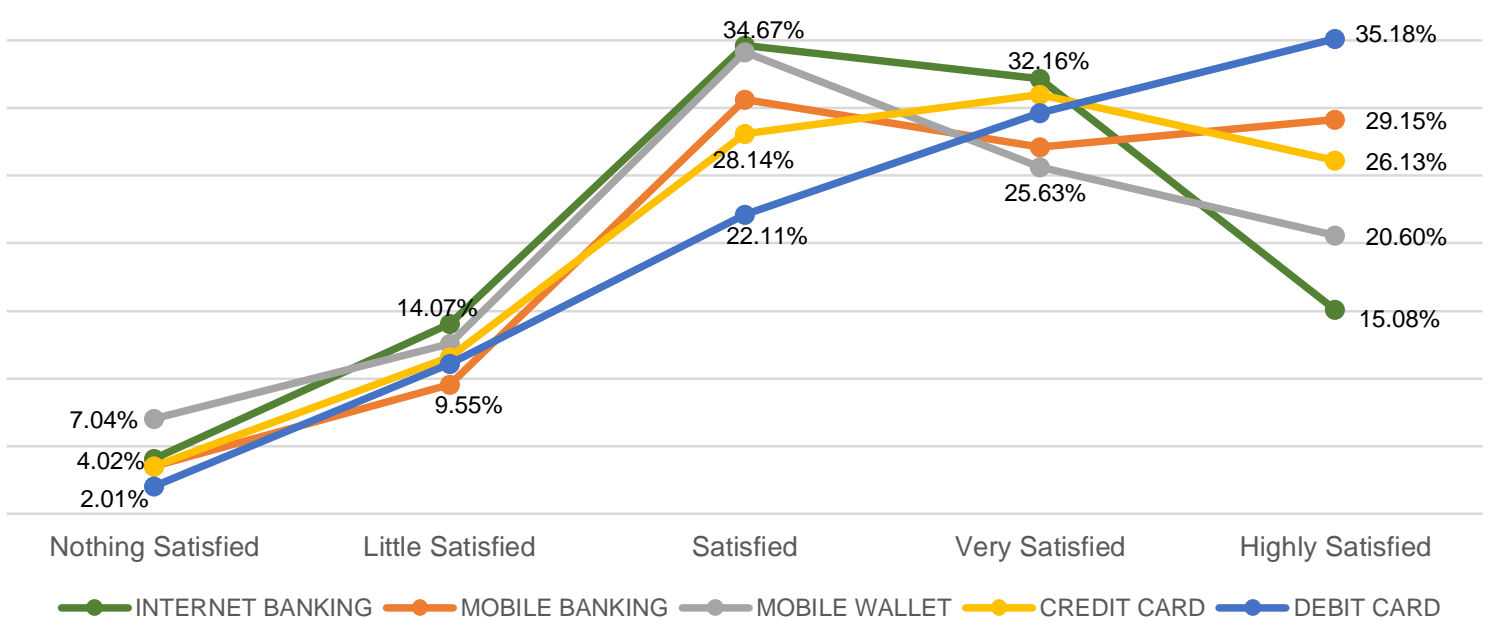

Figure 6. Security in digital financial services (own)

As in the previous case, Figure 7 shows us a satisfactory trend of $40.20 \%$ of those interviewed, where they perceive a greater presence of the Low trailing fee dimension in the Internet Banking service. 


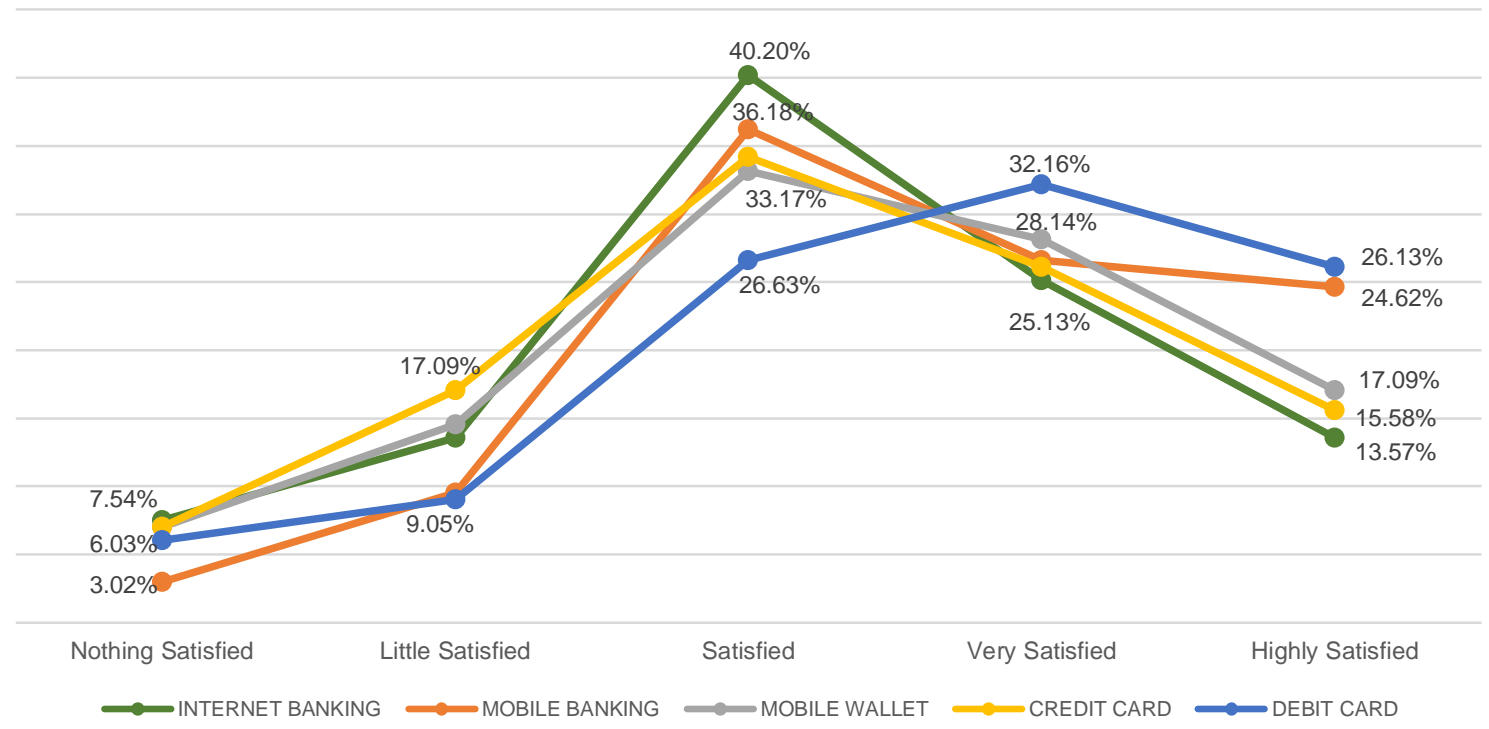

Figure 7. Low service charge in digital financial services (own)

For the Accurate timing dimension, the surveyed perceive this dimension with greater satisfaction in the Debit Card systems with $38.69 \%$, Credit Card reflecting $36.18 \%$ and finally the Internet Banking service with $34.17 \%$, as we can see in Figure 8.

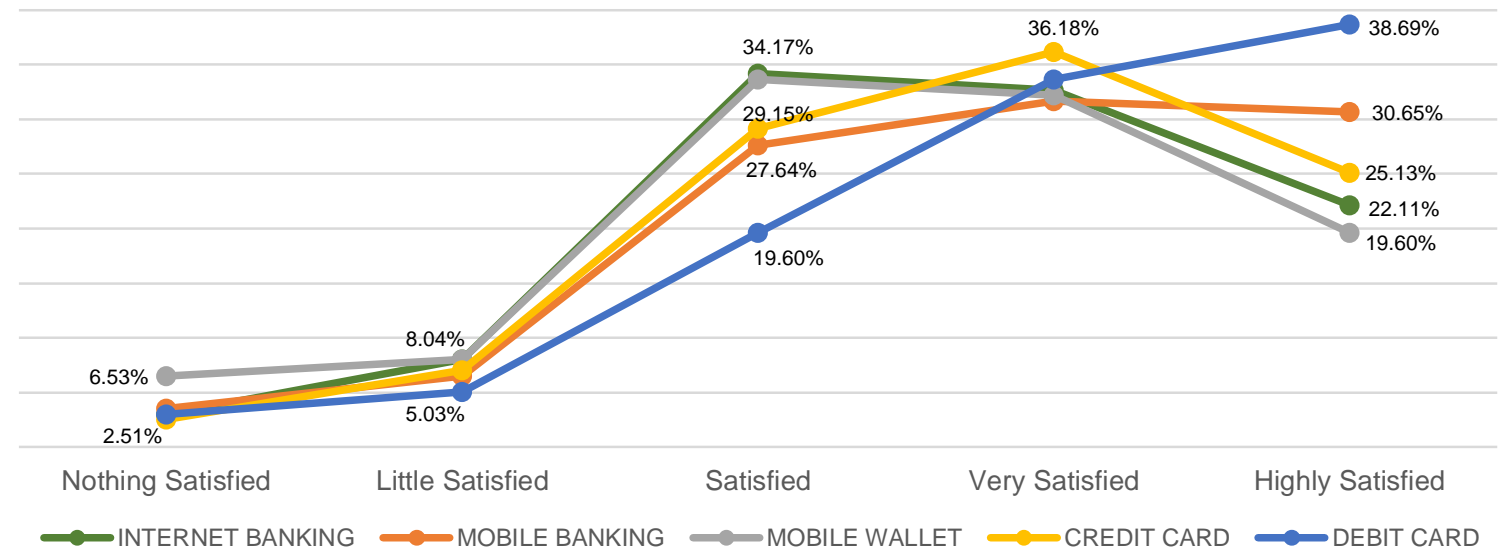

Figure 8. Accurate timing in digital financial services (own)

In Figure 8, we can observe the behavior of the Online Monthly statement dimension in the different Digital Financial Systems and how there is an extremely satisfactory level in the Debit Card with $38.69 \%$ versus $23.62 \%$ of the Mobile Wallet service. 


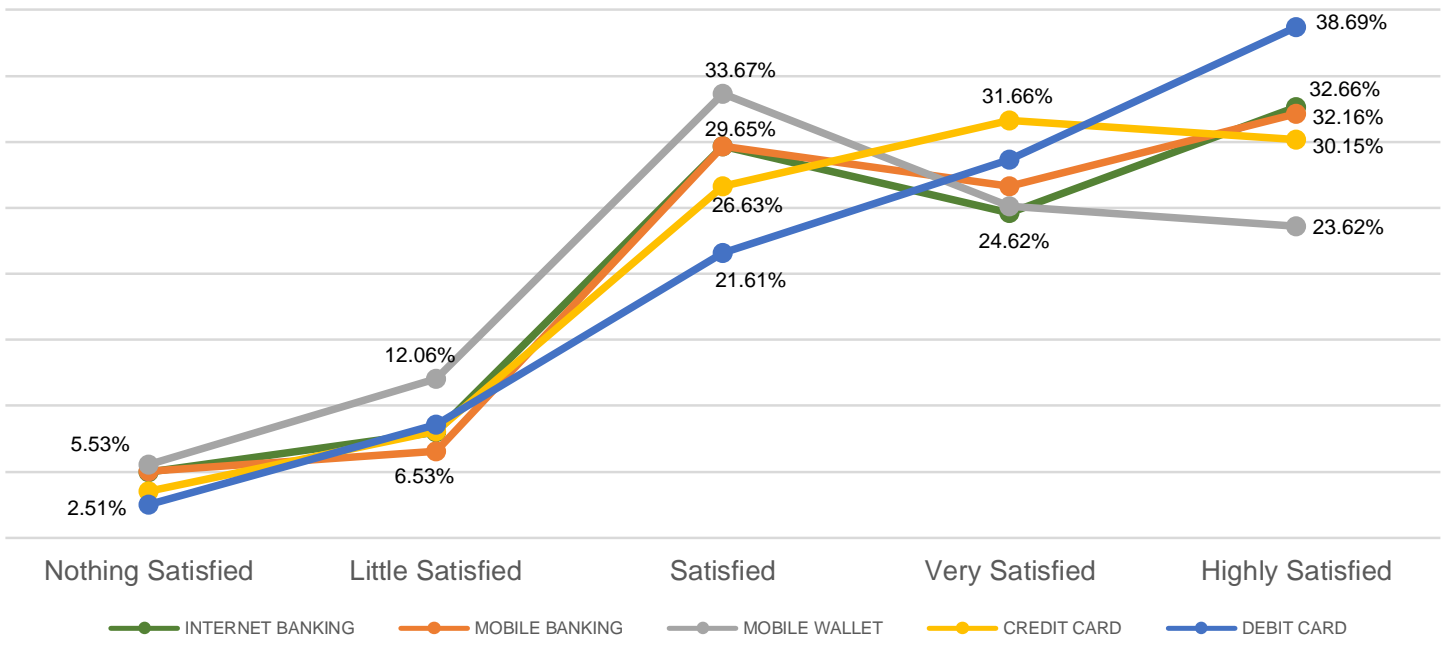

Figure 9. Online monthly statement in digital financial services (own)

In the following figure, we can see the results obtained in the analysis of the Quick financial decision making dimension, showing a greater inclination in the "satisfaction" dimension in the Mobile Wallet system with 35.68\%, followed by Debit Cards with $35.18 \%$.

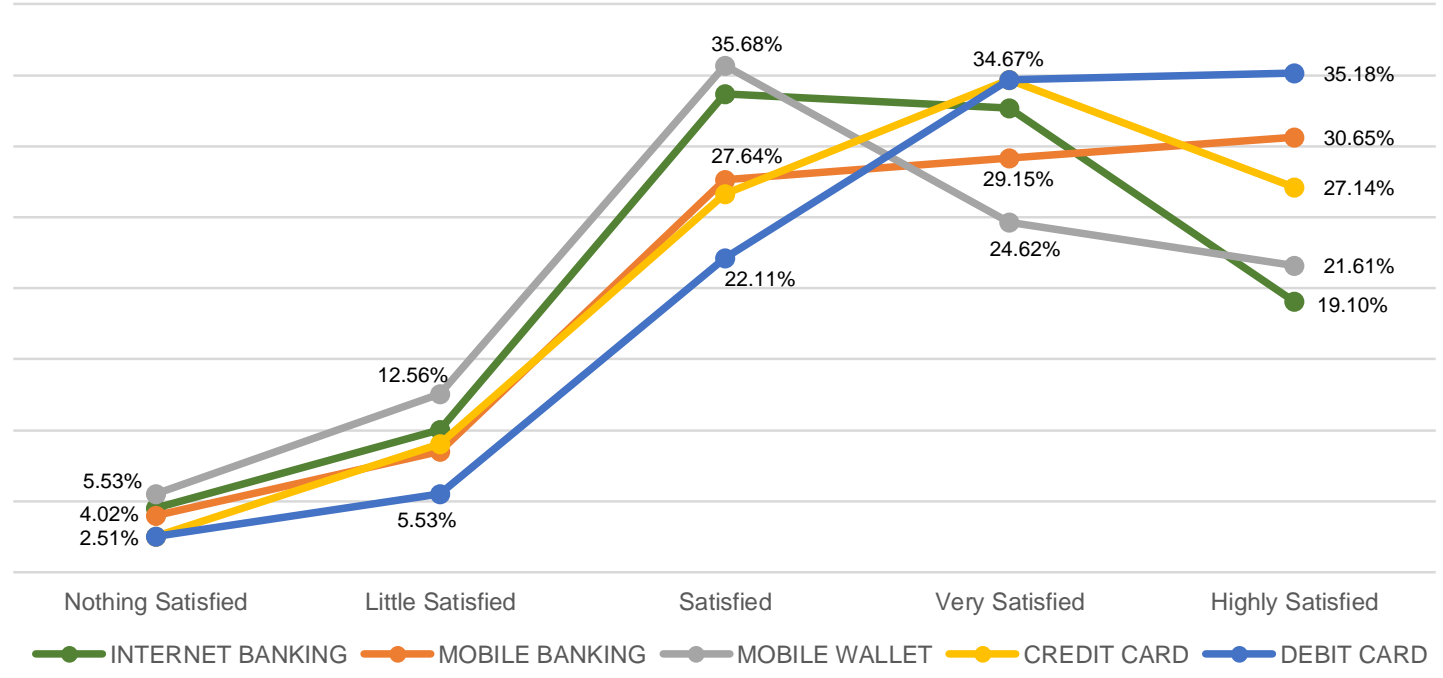

Figure 10. Quick financial decision making in Digital Financial Services (own)

In the case of Figure 10, where the Interbank account accessibility level is analyzed, a relative response to highly satisfied is detected in the Mobile Banking system with 45.23\%, whereas Mobile Wallet obtained 27.64\%. 


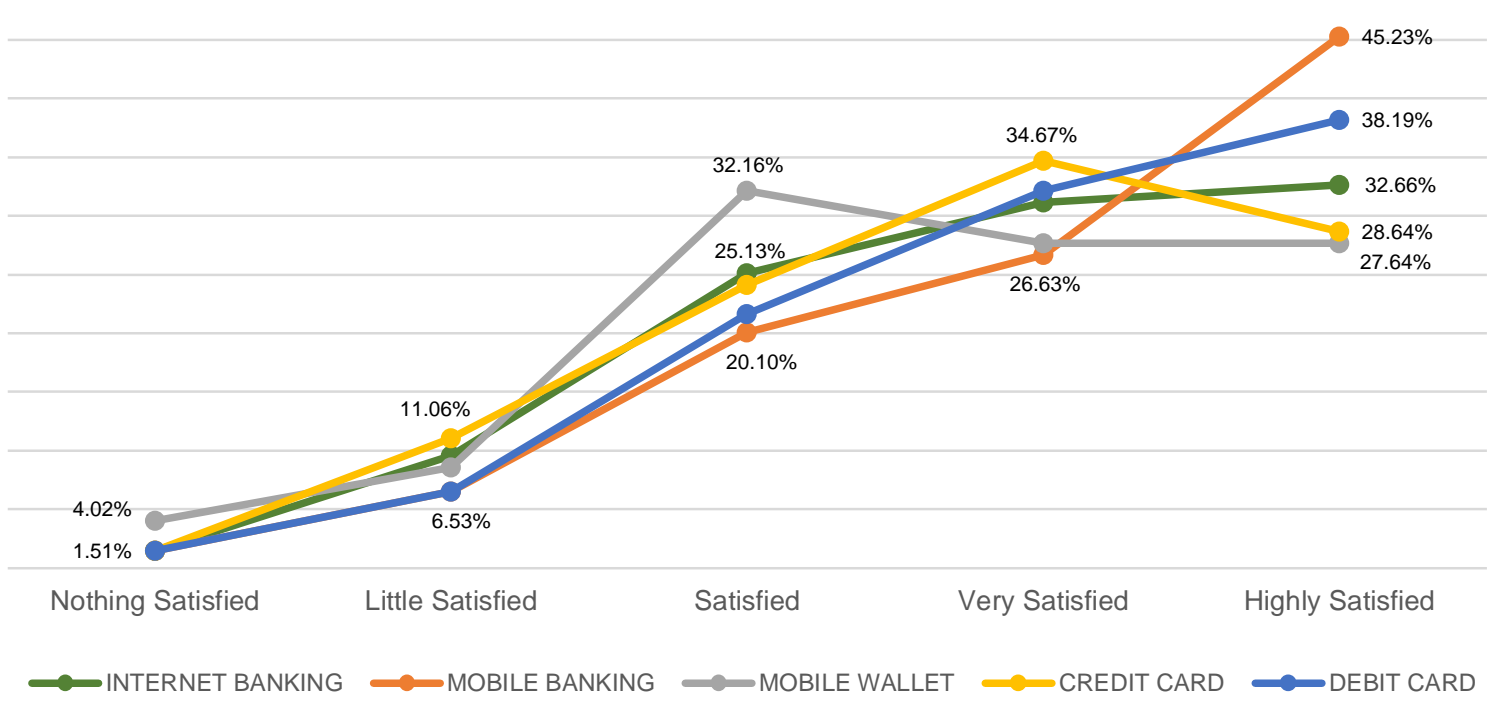

Figure 11. Easy interbank account facility in digital financial services (own)

Regarding Internet Connectivity, the interviewees expressed that this dimension is extremely satisfactory in Mobile Banking systems with $45.73 \%$ and in Debit Cards with 40.20\%. On the contrary, Credit Card only presented 26.63\%; see Figure 12.

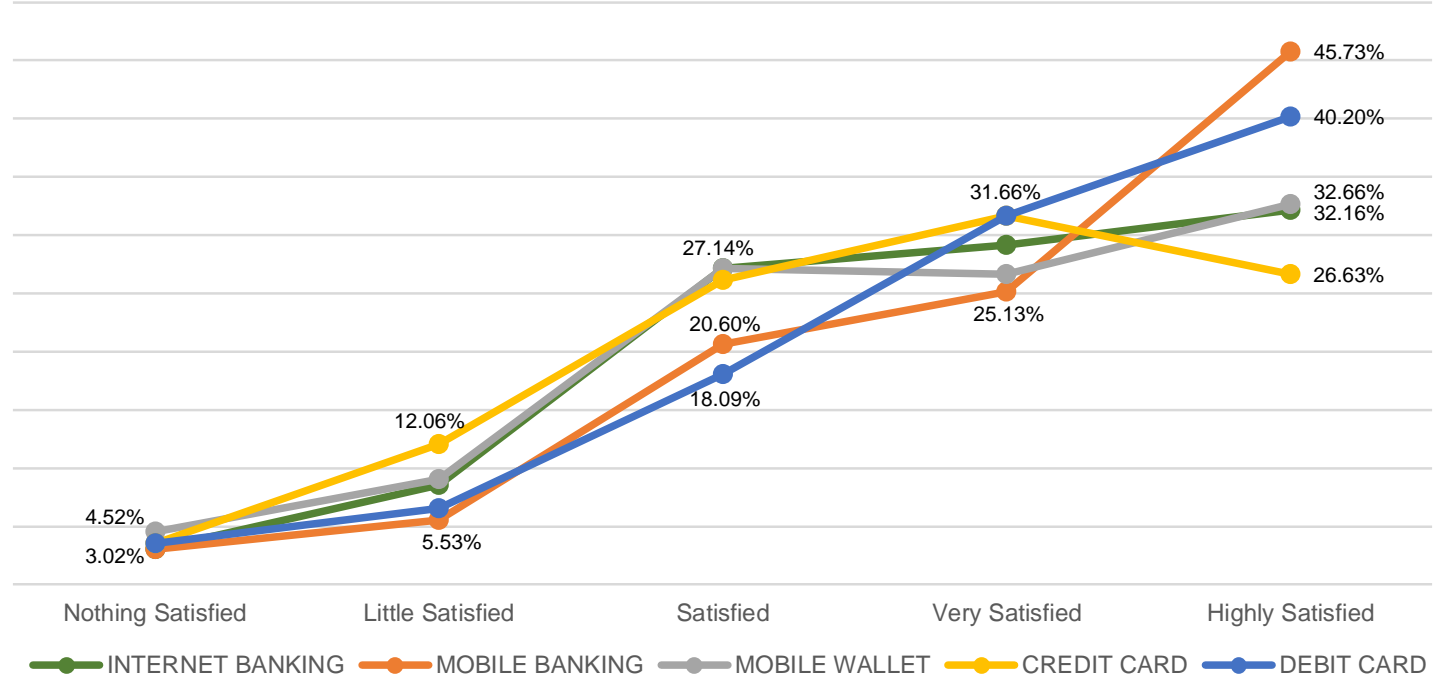

Figure 12. Internet connectivity in digital financial services (own)

Finally, the Portability dimension presented a response of 54.77\%, as highly satisfied, in Debit Cards, while Internet Banking presented 26.13\%, as we can see in Figure 13. 


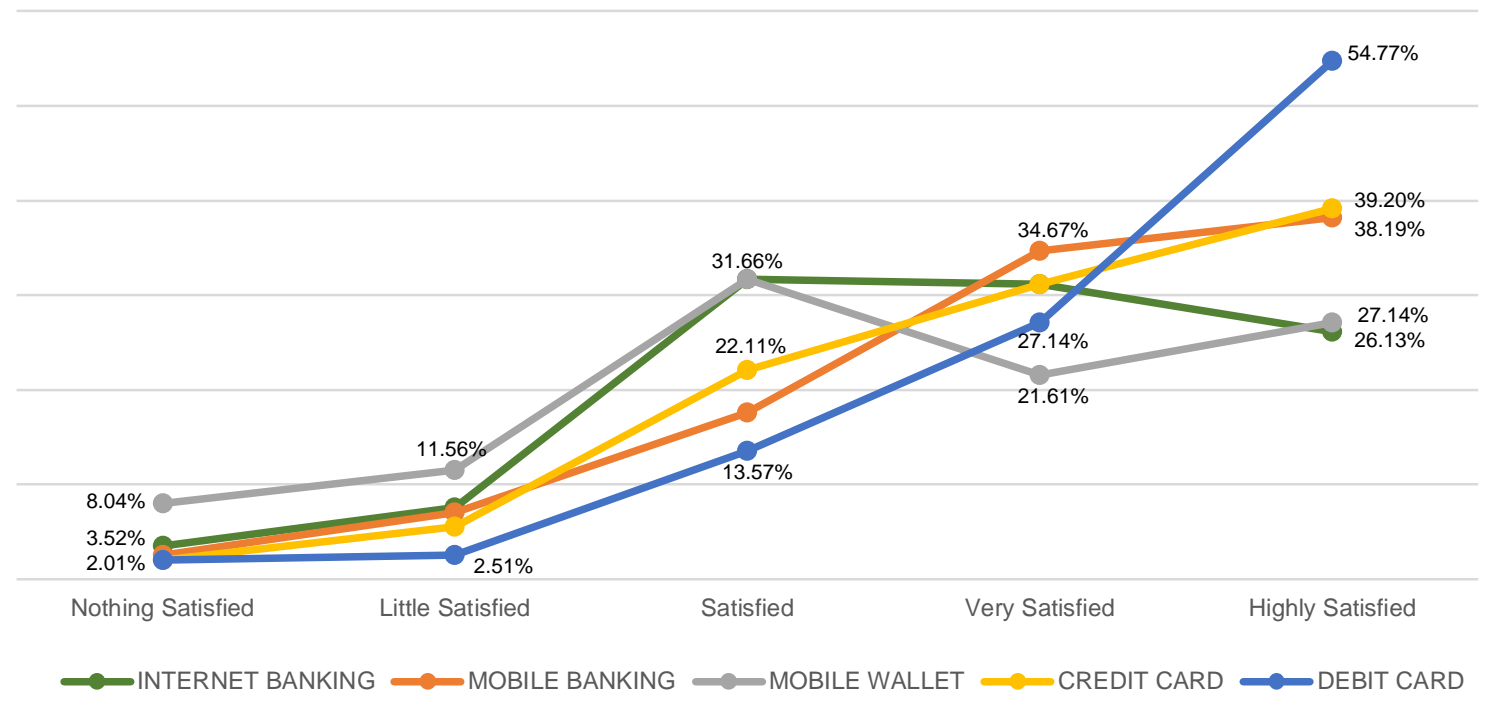

Figure 13. Usability in digital financial services (own)

\section{Discussion}

Although the level of study is limited to a descriptive analysis, it was observed that of the main digital services offered by financial institutions such as Internet Banking, Mobile Banking, Mobile Wallet, Credit Card and Debit Card, a positive trend was obtained. Student's perception was extremely satisfactory towards Debit Card services, especially on the indicators of Adaptability, Affordability, Security, User-friendliness, Accurate timing, Online Monthly statement and Portability. In addition, the Mobile Banking services had a positive impact on the Interbank account accessibility and Internet Connectivity.

On the contrary, Durai and Stella (2019) in their research found that Portability, Convenience, Accurate timing, and Interbank account accessibility have a positive impact on Mobile Banking services. In addition, they detected that Low trailing fee and Accurate timing have a significant impact on Mobile wallet services (apps).

Wibella, Fahmi and Saptono (2018) detected in their study "Factors Affecting Consumer Acceptance of Digital Financial Inclusion; An Anecdotal Evidence from Bogor City, Indonesia" that the aspects of perceived credibility and ease of use are the indicators that most influence the use of digital financial services by users.

\section{Conclusion}

The perception of population about digital financial services is very important, especially among young adults because they will be next generation decision makers. Young adults are a powerful consumer-spending group in their own way and their adoption of digital financial services will contribute to increase financial inclusion in countries. Unlike the existing literature that in general study users acceptance of digital banking and financial services, this study focuses in university students perception about digital financial services.

The results lead us to think that, in a Latin American context, the university population has a better perception of the use of the debit card and mobile banking systems. Results also show an opportunity for financial institutions to provide information about the convenience of the internet banking, mobile wallet and credit cards, to generate a better perception of them, especially among young adults.

\section{Limitations}

It is clear that a hypothetical-deductive method, that allows us to determine how students perceive the digital financial services, requires a bigger sample. Then, this research is considered as a first approach of the analysis of the Veracruz university students' perception about digital financial services. It could encourage other studies to continue in this same line of research to try to explore in larger populations and in different contexts how this phenomenon behaves. 


\section{References}

Alcívar Villao, J., \& Franco Nieto, J. (2016). Análisis del Uso de la Banca Electrónica en Personas Mayores a 40 Años en la Ciudad de Guayaquil: Caso de Estudio Página Web y App Móvil. Guayaquil, Ecuador. Retrieved from https://bit.ly/3jrr34D

Alliance for Financial Inclusion (AFI). (2016). Digital Financial Services. Basic Terminology. Retrieved from https://bit.ly/2EC39UA

Álvarez Castanon, L., Paramo Ricoy, T., \& Carpio Mendoza, J. (2012). De la inclusión financiera a la intervención social: Una experiencia en el sureste de México. Nova scientia, 4(7), 125-152.

Ariffin, M., Sulong, Z., \& Abdullah, A. (2017). Students' perception towards financial literacy and saving behaviour. World Applied Sciences Journal, 35(10), 2194-2201. https://doi.org/10.5829/idosi.wasj.2017.2194.2201

Ávila Díaz, W. (2013). Hacia una reflexión histórica de las TIC. Hallazgos, 10(19), 213-233.

Babajic, A., Okicic, J., \& Kokorovic, M. (2018). Identification of barriers to financial inclusion among youth. International Business Research, 11(7), 120-129. https://doi.org/10.5539/ibr.v11n7p120

Consultative Group to Assist the Poor (CGAP). (2015). What is digital financial inclusion and why does it matter?. Retrieved from https://bit.ly/2QoVkEz

Damodaran, A. (2013). Financial inclusion: issues and challenges. Akgec International Journal of Technology, 4(2), 54-59.

Durai, T., \& Stella, G. (2019). Digital finance and its impact on financial inclusion. International Journal of Emerging Technologies and Innovative Research, 6(1), 122-127.

Escalera-Chávez, M., Tejeda-Peña, E., \& García-Santillán, A. (2017). Uso de los servicios financieros. Estudio Empírico En Estudiantes Universitarios. International Journal of Developmental and Educational Psychology, 4(1).

Finau, G., Rika N., \& Samuwai, J. (2017). Perceptions of digital financial services in Rural Fiji. Information Technologies and International Development, 12(4), 11-21.

Gonzales Hernández, A. (2017). El Desarrollo de la Banca Electrónica y la Aceptación de los Clientes de Lima Metropolitana de los 4 Principales Bancos del Perú. Lima, Perú. Unpublished Bachelor's Thesis. Universidad San Ignacio de Loyola.

Katz, R. (2012). Banda Ancha, Digitalización y Desarrollo. Columbia Institute for Tele-Information. Retrieved from https://bit.ly/3leV1dP

Organización para la Cooperación y el Desarrollo Económicos (OCDE/BID). (2016). Políticas de banda ancha para América Latina y el Caribe: un manual para la economía digital. OECD Publishing, Paris. https://doi.org/10.1787/9789264259027-es

Organización para la Cooperación y el Desarrollo Económicos (OCDE). (2018). Plataformas digitales y competencia en México. Retrieved from http://oe.cd/dpcm

Peterson, K. (2018). Impact of digital finance on financial inclusion and stability. Essex Business School, University of Essex, UK. Retrieved from https://doi.org/10.1016/j.bir.2017.12.003

Preciado-Ortiz, C., \& Moreno Valdovinos, J. (2015). Análisis De Percepción de los Servicios Financieros Móviles como Catalizadores de la Inclusión Financiera: Caso Cd. De Tecolotlán, Jalisco, México. Retrieved from https://bit.ly/2FPOdTs

Redelinghuis, A., \& Rensleigh, C. (2010). Customer perceptions on Internet banking information protection. $S A$ Journal of Information Management, 12(1), Art. 444. https://doi.org/10.4102/sajim.v12i1.444

Singhania, S., \& Sardana, V. (2018). Digital finance: perceptions of the Indian consumer. Conference: Emerging Paradigms of Digitization: A Management Perspective, 1 .

Torres Fragoso, J., \& Luna Espinoza, I. (2017). Evaluación de la percepción de la calidad de los servicios bancarios mediante el modelo SERVPERF. Contaduría y Administración, 62(4), 1270-1293. https://doi.org/10.1016/j.cya.2016.01.009

Torres Gastelú, C. A. (2015). Percepción de estudiantes universitarios sobre el modelo educativo y sus competencias en TIC. Educere, 19(62), 145-156. 
Varcoe, K. P., Peterson, S. S., Wooten Swanson, P., \& Johns, M. C. (2010). What do teens want to know about money-a comparison of 1998 and 2008. Family and Consumer Sciences Research Journal, 38, 360-371. https://dx.doi.org/10.1111/j.1552-3934.2010.00032.x

Vargas Melgarejo, L. M. (1994). Sobre el concepto de percepción. Alteridades, 4(8), 47-53.

Wee, C., Bin, M., Zakuan, N., Mohd, M., Ismail, K., \& Ishak, N. (2014). Consumers Perception, Purchase Intention and Actual Purchase Behavior of Organic Food Products. Review of Integrative Business and Economics Research, 3(2), 378-397.

Wibella, N., Fahmi, I., \& Saptono, I. (2018). Factors affecting consumer acceptance of digital financial inclusion; an anecdotal evidence from bogor city. Independent Journal of Management \& Production, 9, 1338. https://doi.org/10.14807/ijmp.v9i4.824

Widjana, M. A., \& Rachmat, B. (2011). Factors determining acceptance level of internet banking implementation. Journal of Economics Business and Accountanct Ventura, 14(2), 161-174.

World Bank. (2012). Information and communications for development. Retrieved from https://bit.ly/2YyHa81

World Bank. (2014). Tecnologías de la Información y las Comunicaciones: Resultados del sector. Retrieved from https://bit.ly/3gC7WTD

World Bank. (2018). La inclusión financiera es un factor clave para reducir la pobreza e impulsar la prosperidad. Retrieved from https://bit.ly/2CXACsb

World Bank. (2019). Tecnologías de la Información y las Comunicaciones (i). Retrieved from https://bit.ly/2CXACsb

\section{Copyrights}

Copyright for this article is retained by the author(s), with first publication rights granted to the journal.

This is an open-access article distributed under the terms and conditions of the Creative Commons Attribution license (http://creativecommons.org/licenses/by/4.0/). 